\title{
POŠTA
}

TELEKOMUNIKÁCIE A

ELEKTRONICKY OBCHOD

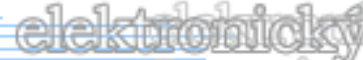

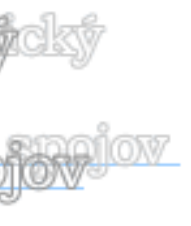

\section{MAPOVANIE PODNIKOVÝCH PROCESOV V POŠTOVOM PODNIKU}

\author{
Martina Kováčiková ${ }^{1}$, Eva Vojtková ${ }^{2}$
}

\begin{abstract}
The paper deals with the issue of process management, specifically focuses on the demonstration of processing the processes to the path diagrams. The issue of process management is closer specified to the processes in the area of collection and delivering of shipments.
\end{abstract}

Keywords: Process. Process management. Process Mapping. Improvement of business processes.

Úvod.

Zlepšovanie podnikových procesov sa stalo bežnou súčast'ou vel'kých i malých spoločností. Podnik od zlepšovania očakáva najmä spokojnost' zákazníkov, zvýšenie podielu na trhu, ako aj zlepšenie podmienok hospodárenia vo vnútri podniku. Na to, aby mohlo byt' zlepšenie uskutočnené, je potrebné si procesy identifikovat' a určit' miesto, ktoré spôsobuje problémy vo fungovaní procesov. V súvislosti s touto problematikou sme sa zamerali na sledovanie procesov vybraného poštového podniku. Problematika procesného riadenia je užšie špecifikovaná na procesy $\mathrm{v}$ oblasti vyberania a dodávania zásielok a ich mapovanie na báze dráhových diagramov.

\section{Teoretické východiská.}

Slovo „proces“ sa v poslednom období dostalo na výslnie manažérskeho podnikatel'ského slovníka. Nájdeme ho bezmála všade - od odborných publikácií až po tlačové komentáre. Často je však použitie nepresné alebo úplne nesprávne. [1] je dna $\mathrm{z}$ definícií uvádza proces nasledovne: Proces je organizovaná skupina vzájomne prepojených činností, ktoré spoločne vytvárajú výsledky hodnotné pre zákazníka. [4]

Podl'a Řepu slovo proces sa dá používat' takmer kedykol'vek a takmer v akomkol'vek význame. Niekedy však zaniká híbka významu, ktorý sa za týmto nenápadným pojmom skrýva. Zaniká, že premýšl'at' procesne znamená predovšetkým dôkladne zmenit' tradičný náhl'ad na takmer čokol'vek v živote organizácie. Že to znamená napríklad opustit' predstavu hierarchickej štruktúry, ako základu organizácie firmy, mýtus "manažérskej zodpovednosti" za prácu podriadených a z toho logicky plynúce nezodpovednosti "podriadených". Znamená to, ale aj pochopit' podstatu zmyslu vývoja technológií a predovšetkým podstatu jeho úlohy vo vývoji organizácie. [5].

\footnotetext{
${ }^{1}$ Ing. Martina Kováčiková, PhD., Katedra spojov, Fakulta prevádzky a ekonomiky dopravy a spojov, Žilinská univerzita v Žiline, Univerzitná 1, 01026 Žilina

tel.: +421415133106

e-mail: martina.kovacikova@fpedas.uniza.sk
}

${ }^{2}$ Ing. Eva Vojtková, študent Katedry spojov, Žilinská univerzita v Žiline, Univerzitná 1, 01026 Žilina e-mail: vojtkova.e@gmail.com 
Riadenie procesu je činnost', ktorá využíva znalosti, schopnosti, metódy, nástroje a systém k tomu, aby identifikovala, popisovala, merala, riadila, hodnotila a zlepšovala procesy so zámerom efektívneho pokrytia potrieb zákazníka procesu. [7] Ciel’om procesného riadenia je rozvíjat' a optimalizovat' chod organizácie.

Základnou úlohou pri budovaní procesne riadenej organizácie je potreba zmapovat' procesy v organizácii, klasifikovat' a vytvorit' si taký pohl’ad na danú organizáciu, ktorý pomôže efektívne využívat' technológie a zistit', aké zmeny to so sebou prinesie. Procesné mapovanie tvorí overený analytický a komunikačný nástroj, určený k optimalizácii terajších procesov a k zavedeniu novej procesne orientovanej štruktúry firiem. Je to vhodný nástroj procesného riadenia, ktorý je možno použit' $\mathrm{k}$ lepšiemu pochopeniu terajších firemných procesov a k zrušeniu alebo zjednodušeniu tých procesov, ktoré vyžadujú zmenu. [7]

$\mathrm{V}$ teórii procesného riadenia existuje množstvo rôznych druhov a typov diagramov, ktorých účelom je vizuálna dokumentácia procesného toku. Tieto diagramy majú ul'ahčit' komunikáciu medzi pracovníkmi, poskytnút' rýchle odhalenie problémov v procesoch, tiež prispôsobit' podnikové procesy požiadavkám zákazníka. (jednoduché situačné náčrty ako napr. SIPOC diagram, stromové organizačné štruktúry a hierarchické modely - diagramy presunu, špagetové diagramy, jednoduché procesné mapy a dráhové diagramy obsahujúce vizuálne informácie o sledoch pracovných činností...)

\section{Ciel'}

Primárnym ciel'om príspevku je poukázat' na možnosti využitia dráhových diagramov pre podporu procesného riadenia a tiež mapovanie situácie $\mathrm{v}$ oblasti sledovaných procesov pre podporu zlepšenia podnikových procesov v oblasti vyberania a dodávania zásielok expresnej služby vo vybranom poštovom podniku.

\section{Materiál a metodika.}

Objektom skúmania je proces vyberania a dodania zásielok expresnej služby vybraného poštového operátora. Pri spracovaní práce boli uplatnené nasledovné postupy:

- zber informácií o danej problematike, určenie parciálnych a čiastkových ciel'ov,

- definovanie sledovaných podnikových procesov, zostavenie mapy procesov $\mathrm{k}$ sledovaným procesom,

\section{Výsledky a diskusia.}

Dráhové diagramy v štandarde BPMN používajú k zápisu informácií základný súbor znakov pre proces, začiatok/koniec, rozhodovanie, procedúru, dokument... Za účelom návrhu dráhových diagramov sme si v nasledujúcom texte vybrali symboly pre mapovanie procesu: začiatok/koniec, proces, rozhodnutie, dokument, pracovný tok, tok informácie a vzt’ah. Poštový operátor, $\mathrm{v}$ rámci ktorého sme riešili mapovanie procesov, bude $\mathrm{v}$ d’alšom texte z dôvodu zachovania neutrality, uvádzaný len ako vybraný poštový operátor.

- Vyberanie expresných zásielok. Nasledovný text uvádza popis vyberania expresných zásielok. V prípade realizácie odosielania balíkových zásielok zmluvný partner vypíše/vytlačí štítky a nalepí ich na balíky spolu s d'alšími nálepkami. Balík musí obsahovat' presnú adresu odosielatel'a, adresu a telefónne číslo adresáta. Prepravu je možné nahlásit' priamo $\mathrm{v}$ distribučnom stredisku, kde putujú všetky informácie $\mathrm{o}$ zásielke z prepravného štítka. Firmy, ktoré posielajú viac ako 10 balíkov denne, sú vybavené zákazníckym softvérom. Jednoduchý softvér umožňuje vyplnit' prepravné štítky, poslat' údaje zo štítkov do centra a následne ich vytlačit'. Je určený pre podporu administratívy. Menšie podniky nahlasujú prepravu priradenému kuriérovi, ktorému sa 
oznámi len počet balíkov. Stredisko a kuriér si na základe týchto informácií optimalizujú trasy. Pokial' nenastanú nepredvídané udalosti, kuriér prichádza $\mathrm{k}$ zákazníkovi približne $\mathrm{v}$ rovnakom časovom intervale. Ak ide o vyšší počet nahlásených balíkov, stredisko posiela špeciálne auto. Procesy vyberania expresných zásielok sme spracovali prostredníctvom nižšie uvedeného dráhového diagramu.

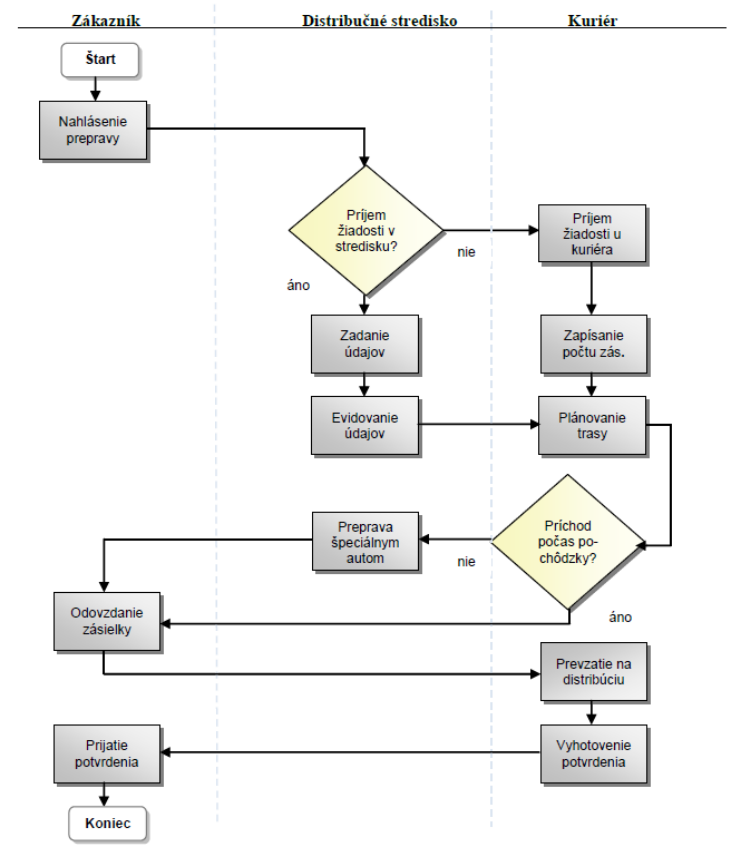

Obr. 1 Vyberanie expresných zásielok

Na konci dňa sú vybrané balíkové zásielky zo všetkých diep posielané hlavnou linkou do triediaceho strediska. Zo všetkých diep sú balíkové zásielky prepravované neodvážené.

Po príchode zásielok do distribučného centra sa na elektronickej váhe zistí ich hmotnost', ktorá je priradená $\mathrm{k}$ číslu balíka a automaticky sa zaregistruje (v prípade nadmernej hmotnosti sa táto zohl'adní vo faktúre). Nasleduje triedenie a preprava do adresného depa. Po roztriedení a spísaní rozvozového listu môže kuriér, prip. depo poslat' avízo zákazníkovi.

- Dodávanie a vyúčtovanie expresných zásielok. Balíková zásielka nemusí byt' doručená len na adresu určenia, adresát sa môže skontaktovat's kuriérom a dohodnút' si aj iné miesto doručenia, prípadne si môže zásielku vyzdvihnút' v depe.

V prípade nedoručenia zásielky na prvý pokus, zásielka ide naspät do depa, kde je naskenovaná a zaznamená sa nedoručenie zásielky. Doručovanie sa opakuje na druhý deň a ak je opät' neúspešné, zásielka sa vráti zmluvnému partnerovi. Dôvod nedoručenia môže byt': nesprávna adresa adresáta, nesprávne telefónne číslo, odmietnutie prijatia resp. zaplatenia dobierky. Ak zásielku je možné doručit' a je na dobierku, kuriér prevezme $\mathrm{v}$ hotovosti požadovanú sumu a po podpísaní rozvozového listu, odovzdá zásielku adresátovi (príp. inej oprávnenej osobe). Dnes už nie je nič výnimočné, že počas celej prepravy si zákazníci môžu svoju zásielku sledovat' (Track\&Trace). Po naskenovaní zásielky v hlavnom distribučnom centre je možné ju kontrolovat' zadaním čísla zásielky do systému poštového operátora. Po doručení zásielky nasleduje vyúčtovanie - fakturácia. Služby sú vyúčtované vždy zmluvnému partnerovi (poverujúci), nikdy nie adresátovi (prijímatel') zásielky. Fakturácia sa vykonáva podl'a dohody, zväčša jedenkrát za mesiac. Na faktúre je jedna suma, ktorá obsahuje prepravné a doplnkové služby spolu. V prílohe faktúry sú podrobne rozpísané hmotnosti a poplatky za jednotlivé balíkové zásielky. [1] 


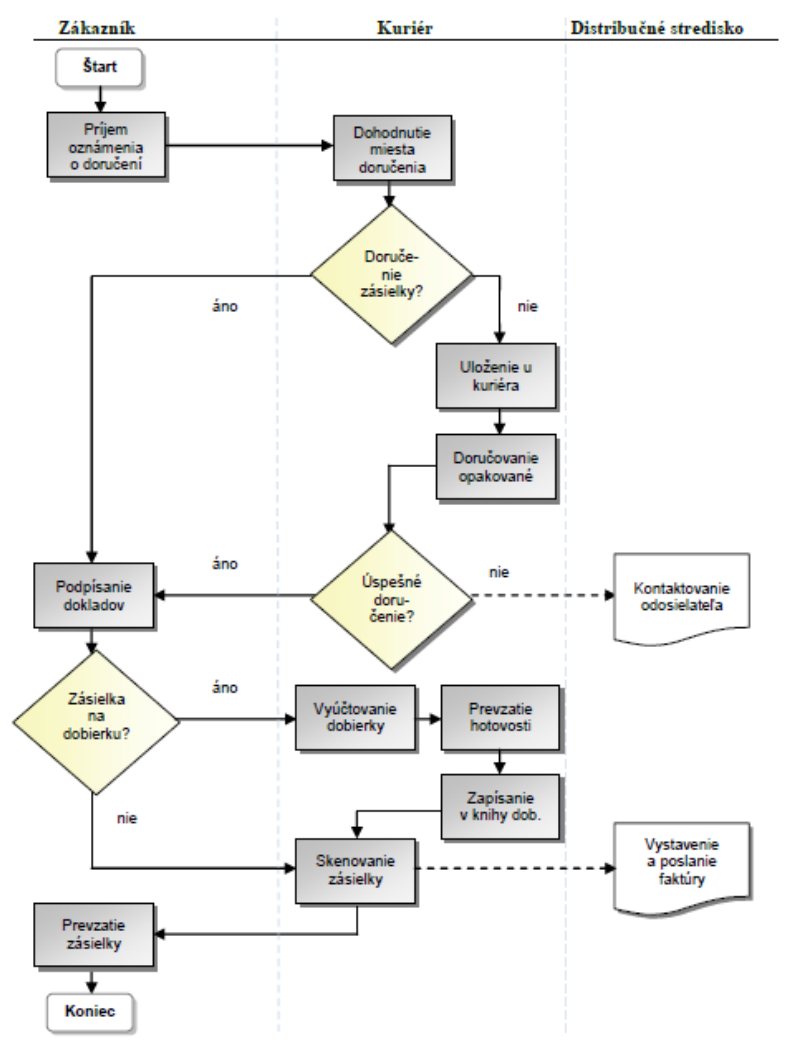

Obr. 2 Dodávanie a vyúčtovanie expresných zásielok

V prípade nedoručenia zásielky na prvý pokus, zásielka ide naspät' do depa, kde je naskenovaná a zaznamená sa nedoručenie zásielky. Doručovanie sa opakuje na druhý deň a ak je opät' neúspešné, zásielka sa vráti zmluvnému partnerovi. Dôvod nedoručenia môže byt': nesprávna adresa adresáta, nesprávne telefónne číslo, odmietnutie prijatia resp. zaplatenia dobierky. Ak zásielku je možné doručit' a je na dobierku, kuriér prevezme $\mathrm{v}$ hotovosti požadovanú sumu a po podpísaní rozvozového listu, odovzdá zásielku adresátovi (príp. inej oprávnenej osobe). Dnes už nie je nič výnimočné, že počas celej prepravy si zákazníci môžu svoju zásielku sledovat' (Track\&Trace). Po naskenovaní zásielky v hlavnom distribučnom centre je možné ju kontrolovat' zadaním čísla zásielky do systému poštového operátora. Po doručení zásielky nasleduje vyúčtovanie - fakturácia. Služby sú vyúčtované vždy zmluvnému partnerovi (poverujúci), nikdy nie adresátovi (prijímatel') zásielky. Fakturácia sa vykonáva podl'a dohody, zväčša jedenkrát za mesiac. Na faktúre je jedna suma, ktorá obsahuje prepravné a doplnkové služby spolu. V prílohe faktúry sú podrobne rozpísané hmotnosti a poplatky za jednotlivé balíkové zásielky. [1]

$\mathrm{Na}$ základe mapovania procesov bol v súvislosti s riešenou problematikou vytvorený dotazník smerovaný priamo na určité procesy voblasti podania a dodania expresných balíkových zásielok, ktorý bol priamo zameraný na spokojnost' zákazníkov poštového operátora. Zároveň bolo uskutočnené vlastné meranie podania a dodania expresných balíkových zásielok u skúmaného poštového operátora. V súvislosti s vykonanými analýzami, prieskumom a pozorovaním je možné koncipovat' návrh opatrení v konkrétnych oblastiach, ktoré by mohli zlepšit' sledované procesy: vytvorenie možnosti stanovenia a overenia hmotnosti balíkovej zásielky skôr ako v distribučnom centre, zvýšenie limitu hmotnosti, úprava času pri uzatváraní zmluvy, vytvorenie možnosti zvýšenia poistného. 


\section{Záver}

Poštový operátor, ktorý chce výrazne zvýšit' svoju účast' na trhu, musí neustále sledovat' priebeh a jednotlivé fázy procesov. Svoje poznatky a skúsenosti premietnut' do návrhu zmien na zlepšenie tých procesov, od ktorých očakáva, že podniku prinesú výrazný prospech prostredníctvom spokojných zákazníkov.

\section{Literatúra}

[1] BOROVSKÝ, J. MANAŽMENT ZMIEN - CESTA K RASTU KONKURENCIESCHOPNOSTI. BRATISLAVA: EUROUNION, 2005. 142 S. ISBN 80-88984-66-1.

[2] DŽUBÁKOVÁ,M. - KAPUSTA,J. - LICHNEROVÁ,L. Manažment kvality - Vybrané metódy zlepšovania kvality. Bratislava: EKONÓM, 2011. 140 s. ISBN 978-80-225-3198-6.

[3] FIALA, J. - MINISTR, J. Pruvodce analýzou a modelování procesu. Ostrava: VŠB Technická univerzita, 2003. 110 s. ISBN 20-248-0500-6.

[4] HAMMER, M. AGENDA 21. PRAHA: MANAGEMENT PRESS, 2002. 62 S. ISBN 807261-074-0. ĎAĎO, J., MATEIDES, A.: Spokojnost' zákazníka a metódy jej merania, 2. diel - metódy, EPOS, Bratislava, 2000, 255 str., ISBN 80-8057-224-0

[5] ŘEPA, V. Procesně řizená organizace. Praha: Grada Publishing, a.s., 2012. 304 s. ISBN 97880-247-4128-4.

[6] ŘEPA, V. Podnikové procesy. 2. vyd. Praha : Grada Publishing, 2007. 288 s. ISBN 978-80247-2252-8.

[7] SVOZILOVÁ, A. Zlepšovaní podnikových procesu. Praha: Grada Publishing, a.s., 2011. 232 s. ISBN 978-80-247-3938-0.

[8] VEBER, J. a kol. Management - základy, prosperita, globalizace. 1. vyd. Praha: Management Press, 2007. 700 s. ISBN 80-7261-029-5.

[9] VOJTKOVÁ, E.: Zlepšovanie podnikových procesov $\mathrm{v}$ oblasti vyberania a dodávania zásielok expresnej služby u vybraného poštového operátora, diplomová práca, Žilinská univerzita v Žiline 2014, vedúci práce: Kováčiková Martina

\section{Grantová podpora}

- Inštitucionálny výskum 5/KS/2014 Návrh Globálneho modelu procesov v podniku služieb

- VEGA 1/1321/12 Výskum nových trendov v manažmente v období globalizácie 